EDUKASIA

JURNAL PENELITIAN PENDIDIKAN ISLAM

http://journal.stainkudus.ac.id/index.php/Edukasia

P-ISSN : 1907-7254; E-ISSN : 2502-3039

Vol. 15 No. 2 Tahun $2020 \mid 293$ - 314

DOI: $10.21043 /$ edukasia.v15i2.8045

\title{
Development and Contextualization of Multicultural Insight-Based Quran Hadith Materials in Madrasah Aliyah
}

\author{
Sukino \\ Postgraduate Program of Institut Agama Islam Negeri Pontianak \\ ariefsukino@yahoo.co.id \\ Wahab \\ Postgraduate Program of Institut Agama Islam Negeri Pontianak \\ abdulwahabassambasi@yahoo.co.id \\ Ahmad Fauzi Murliji \\ Postgraduate Program of Institut Agama Islam Negeri Pontianak \\ arafah09@gmail.com
}

\begin{abstract}
Indonesian Muslims are faced with the realities of life that are multi-ethnic, religious, cultural and linguistic. It must be responded critically as early as possible. The understanding of diversity (multiculturalism) should truly be the foundation of all components of the Muslim community without exception for the students. Therefore this paper intends to answer 1) material content of Quran Hadith with a multicultural perspective at Madrasah Aliyah Negeri 2 Pontianak, and 2) Development and contextualization of Qur'an Hadith material in daily life. This research was categorized as field research and literature study. Data collection methods used were observation, interviews and document analysis. Data analysis was through two models, namely content analysis and Miles and Huberman's model which involved analysis steps, namely: data collection, data reduction, data display, and verification. The authors' findings on this study are that the content of the Quran Hadith with a multicultural perspective in Madrasah Aliyah is carried out by expanding the reading, the meaning of the implementation of tolerance, social ethics, justice, deliberation / democracy concepts which are constructed from the Islamic universal values and moderation (washathiyah) so they can foster a tolerant and empathy (alturism) attitutes to human beings as a manifestation of an obedient servant.
\end{abstract}

Keywords: Contextualization; learning materials; quran hadith; multicultural; Madrasah 


\begin{abstract}
Abstrak
Umat Islam Indonesia dihadapkan pada realitas kehidupan yang multi etnis, religi budaya dan Bahasa, hal ini perlu direspon secara kritis sedini mungkin. Pemahaman akan keberagaman (multikultural) hendaknya benar-benar menjadi pijakan oleh semua komponen umat Islam tanpa terkecuali para peserta didik. Oleh karena itu tulisan ini bermaksud untuk menjawab 1). muatan materi Quran Hadist yang berwawasn multikultural di Madrasah Aliyah Negeri 2 Pontianak, serta 2). Pengembangan dan kontekstualisasi materi Qur'an hadist dalam kehidupan sehari-hari. Penelitian ini termasuk dalam jenis penelitian lapangan dan studi pustaka. Metode pengumpulan data yang dilakukan adalah melalui observasi, wawancara dan analisis dokumen. Analisis data dengan dua model yakni analisis konten dan model model Miles dan Huberman yang memuat langkah-langkah analisis yakni: Data Collection, Data Reduction, Data display, serta verification. Temuan penulis terhadap kajian ini adalah bahwa muatan materi Quran hadist berwawasan multikultural di Madrasah Aliyah dilakukan dengan memperluas pembacaan, pemaknaan atas penerapan konsep toleransi, etika pergaulan, keadilan, musyawarah/demokrasi yang dikonstuksi dari nilai-nilai universal agama Islam dan moderasi Islam (washathiyah), sehingga menumbuhkan sikap toleran, empati (alturisme), kepada sesama manusia sebagai manifestasi hamba yang bertaqwa.
\end{abstract}

Kata Kunci: Kontekstualisasi; materi pembelajaran; quran hadist; multicultural; Madrasah

\title{
A. Introduction
}

The values of Islamic teachings are universal so they can be managed into various visualizations, either in the form of activities or institutions. In the form of activities, Islamic teachings are implemented through acts of good deeds, while in the form of institutions, it is implied by the establishment of schools/madrasah, mosques or hospitals. Educational institutions are the basis for building civilization. Their roles and functions are the society foundations in building and developing a friendly and peaceful national personality. In other words, the role of educational institutions is not limited to the role of creating values, knowledge and skills, but also as a social community institution (Suparlan 2014), (Haningsih 2008).

Islamic Education Institutions are currently facing major challenges, namely the spread of various ideologies, such as political, economic and religious ideals that are not in line with Indonesian vision and philosophy. In the case of transnational religious ideologies such as (Wahabi, Shia, Jamaah Tablig), it has created horizontal conflicts within the Muslim 
community, due to different perspectives on the text of the Qur'an and hadith. In fact, from different views on the text of the Qur'an and Hadith, a small part of the Muslim community displays intolerant behavior towards differences and becomes radical which then transforms into terrorists. It is evidence that the influence of religious understanding has the potential to be a source of intolerance towards differences. The examples of intolerance according to Imparsial in detiknews on November 17, 2019, 31 cases of intolerance were collected from the media and among them were cases of prohibiting certain ethnic cultures and rejection of opposing different beliefs. In addition, Tirto id on August 18, 2020 also reported that there were acts of intolerance towards Solo residents who were considered to follow Shia teachings by dissolving, hitting and destroying property for "midodareni" activity on Saturday, August 8, 2020.

The current phenomenon shows the rise of radical movements and ideas that use religious identity as the base of their movement's doctrine. Muslims need to immediately respond to this phenomenon by returning Islam to its original purpose as the religion of grace for all nature. One of them is by deradicalizing the understanding of religious texts, namely the Qur'an and the Hadiths of the Prophet. This is in line with the research results (Muhammad Harfin Zuhdi 2010) which argue that the deradicalization approach in responding to various movements of Islamic fundamentalism is considered more appropriate than the repressive approach and acts of violence. This approach is expected to be able to provide a solution to the various tensions that have occurred lately as a result of the emergence of terrorism and fundamentalism movements which have destroyed the religion.

According to the authors, the act was carried out as a result of a low religion understanding and self-control. Although we cannot deny that the emergence of this behavior is caused by many very complex factors, such as economic inequality, law and education injustice. But one of the most important factors is exclusivism in understanding Islam as a teaching based on the Qur'an and Hadith and supported by this gap. According to Kusuma (2016), religious understanding plays an important role in radicalism-terrorism behavior. On the basis of a low understanding of religion, a person can commit acts of symbolic or physical violence only triggered by problems of economic inequality or differences in political choices. Therefore, Islamic Education Institutions such as madrasah need to make a variety of concrete efforts to prevent the spread of understandings or ideologies that are contrary to the religious values and philosophies of the Indonesian people through the internalization of moderate Islamic values in the education process in the Islamic schools. 
Learning Quran Hadith in madrasah is an implementation of the curriculum designed by Ministry of Religion. According to the authors, it is still general. So that the education orientation is directed to build a multicultural spirit and teachers must be ready for its development. Books published by the Ministry of Religion or Pendidikan Agama Islam (PAI) Book published by the Ministry of Education and Culture generally present verse and hadith texts with brief meaning. These thematic verses are still very open to be interpreted by educators. The content of the book, especially the meaning of the verse is still very limited so the teacher must be able to contextualize the verse in students' real life. From this point, it can be seen that a study of the material development and its contextualization is urgent.

In the context of a multicultural nation, how to understand the text dynamically contextually becomes the basis for the development of moderate Islam. Islam provides peace for the entire community so Islamic education teachers need to make efforts to contextualize the meaning of the text correctly because not a few people who study religion will make the text of the verse and its meaning become the basis of legitimacy for its various behavior in society. If it is not controlled and the teacher does not provide a contextual understanding, students will have a textual understanding. And it create young generations who were intolerant on the differences.

Within the scope of Madrasah, Qur'an Hadith subject is a sub-subject of Islamic Religious Education which makes the Qur'an and Hadiths as the object of discussion. In this case, Qur'an Hadith is the source of akidah-akhlak, sharia/fiqh (worship, muamalah) so that the study is in each of these elements. In other words, Qur'an Hadith cannot be separated from other sub-subjects of PAI. The characteristics of Qur'an Hadith strives for good and correct reading and writing skills, the meaning of verses in text and context, and practicing their content in daily life. Considering that Qur'an Hadith is the main source of Islamic teachings and the trend that has occurred lately in which Islam is often understood exclusively and the need to solve the above problems is very urgent. One of them is through deradicalization, contextualization of the text of Qur'an verses, the Prophet's hadiths and traditions are a must in every development of learning materials.

Studies that explain this phenomenon are the results of research (Abdul Karim Munthe, 2017:x) that have given several examples of how the Hadiths of the Prophet p.b.u.h and various Arabic terms are often misunderstood by some radicals such as end-time hadiths, about infidels, relations between Muslims and Non-Muslims and other terms. In the results of his study, this phenomenon can then occur due to the understanding factor of some Muslims who then only understand the Qur'an and Hadith outwardly or textually and then just match 
them with socio-political realities carelessly and ignore the understanding methods of the scholars about these religious texts.

Another study that has contributed to provide a multicultural understanding is from Kamal and Junaidi (2018). His research produces textbook with a multicultural perspective as an effort to internalize the diversity values. The two studies above show that the issue of multicultural education still needs to be developed because this nation is rich in diversity so that it is not only seen from one particular perspective. Each region will display a different culture so studies for these themes must also be interdisciplinary. Seeing the open space in the multicultural study, the study that the authors conducted looked at the adaptive, progressive and multicultural learning model of the Quran Hadith in Indonesia. This study becomes a repertoire and a preventive solution for the development of intolerance to diversity in a wide variety of matters. Pendidikan Agama Islam (PAI), especially the material in Quran Hadith subject is one of potential ways in developing the noble values of the nation which are integrated with religion. Islam for Indonesian people is the strongest guideline in life. Moderate universal Islamic values are very easy to develop if it is transformed through a cultural process that is in harmony with local culture. This development method such materials will strengthen the educational foundation in Indonesia which is very pluralist. This is then in line with the spirit and the efforts made in order to create educational institutions that are able to develop the values of diversity amidst diversity (Efendi 2008).

Understanding the problems that have occurred as stated above, it is our common concern that Islamic Religious Education today, especially in relation to Islamic religious learning materials needs to be directed to respond to the phenomenon of the spread of radicalism and acts of terrorism in the name of religion, as a result. from the tendency of intellectualist Islamic religious doctrine and tends to be exclusive.

This paper seeks to elaborate on the extent to which the contextualization of the Qur'an Hadith learning material has a multicultural perspective in Madrasah Aliyah. This paper trys to answer some of the main problems which include the contents of the multicultural insight of Qur'an learning materials in Madrasah Aliyah Negeri 2 Pontianak, as well as the contextualization efforts carried out in daily life. Hopefully, this paper can give preference to Qur'an Hadith teachers in developing multicultural material as a constructive effort in deradicalizing and grounding moderate Islamic values in the midst of a diverse or plural Indonesian society. 


\section{B. Discussion}

\section{The Urgency of Multicultural Education in Islamic Education Learning}

The term of 'multicultural' means cultural diversity and various politeness (Spring and Spring 2018). Whereas in terms of the education context, multicultural is interpreted as a medium for developing human potential that is unique to its social entities that are plural and heterogeneous in cultural, ethnic and religious aspects (Banks 2015). Thus, this meaning has broad implications in the education and teaching process that lasts for the longest. Besides that, the meaning of multiculture in education is a process of self-awareness to recognize and respect and uphold human dignity and values (Chevrier, Nolan, and Whittemore 2013).

In multicultural education programs, the focus of multicultural education is no longer directed to the community based on race, religion, culture that is dominant or mainstream, because it directs the process of understanding tolerance of minority groups to the majority, so that minority groups will be integrated into the culture mainstream or dominant group (Tilaar, 2002:59) Multicultural education is the process of building an attitude of "care" and want to understand the difference or politics of recognition on the diversity of entities in minority people or groups.

The meaning of multicultural education which is developing now is quite diverse and complementary. Muliadi (2012) provides a broader understanding. First, multicultural education is a process of breaking down barriers in social interaction between individuals and groups. Secondly, multicultural education seeks to explore and develop basic human capabilities including abilities in intellectual and emotional aspects. It begins with teaching obedience on the human beings value, respecting human dignity, respecting people with different social, political, religious and cultural status.

Third is education that introduces plurality and pluralism. Plurality is a necessity for modern society nowadays. Plurality is not only understood in terms of ethnic, religious and cultural diversity, but also the diversity of paradigms of thought, understanding the methods or ideas. Thus, it can omit the gap for each group to claim that the group is best to be a model for the other party. Fourth, multicultural education respects ethnic, cultural and religious diversity. Respect and appreciation are positive attitudes that need to be continuously socialized. Such respect is very urgent attitudes to be socialized so that all nations in the world give respect to each other's cultures. Thus, privilage and privacy that only pay attention to certain groups become irrelevant. 
The multicultural education paradigm is built on the basis that the majority group often triggers the occurrence of injustice in various ways because they feel the social group is the most influential in life and control the social system. With such dominant culture, an egoistic, exclusive and stereotypical attitude emerged. Therefore multicultural education in Indonesia needs to be done with the support of strict education regulations.

Selfish, individualistic, and prejudiced attitudes towards other groups often occur in educational institutions. Therefore, multicultural education will lead students to have a comprehensive understanding. They will understand that they cannot be separated from others or realize that they are not biased forced to integrate in other groups. Thus multicultural education will be an appropriate process for students in the introduction and identification of cultural, religious and ethnic diversity within their own and other environments. Finally, they are able to take part in global competition in various life aspects.

In the context of Islamic studies, multiculturalism is seen as one of the supporting components of the inclusive education paradigm and also strengthens national identity in cultural globalization (A. Rohman and Ningsih 2018). It is caused by multiculturalism including cultural aspect that maintaining tolerance is very important. Therefore, tolerance must be promoted by all ethnicities and religions in a country, not only by certain communities (Misrawi 2017).

Islamic education is very strategic in managing multicultural education because it comes from teachings that promote equality among the creatures, including the subjects of Quran Hadith in madrasah. For that reason, study on multiculture integrated in Islamic education subject is important to do.

This research was included as field research as well as qualitative research because it tried to examine the condition of natural objects. In addition, the data generated in this study were more qualitative data that was processed descriptively and interpretatively (Sugiyono, 2014:8-9). Subjects in this study were Quran Hadith teachers in Madrasah Aliyah Negeri 2 Pontianak, while the objects were Quran Hadith material and contextualization of Quran Hadith learning material at Madrasah Aliyah Negeri 2 Pontianak.

Research data were collected by interview, observation and documentation techniques. Interviews were conducted to Quran Hadith teachers of X to XII graders at Madrasah Aliyah Negeri 2 Pontianak. Observations were done during the teaching and learning process, while the study of documents was carried out by examining learning instruments such as the lesson plan and textbook. After the data was collected, it was then 
Sukino, Wahab dan Ahmad Fauzi Murliji

analyzed using the Miles and Huberman models with analysis steps, namely data collection, data reduction, data display and verification.

\section{Multicultural Content of Quran Hadith Material in Madrasah Aliyah}

Quran Hadith learning is general, not all materials taught contain multicultural insights. The material taught is based on the main themes of verses and hadith content elaborated in the Competency Standards and Basic Competence that would be achieved by the student.

The themes of the Qur'an Hadith learning materials include: humans and their duties as caliphs on earth, democracy, sincerity in worship, favor of allah and how to thank, command to preserve the environment, competing in goodness, amar ma 'ruf nahi munkar, simple life patterns and order to support the poor, being fair and honest, tolerance and ethical social relations, human trials, human responsibility towards family and society, work ethic, halal and good food, science and technology.

From the above thematic schemes, it is clear that not all material for learning Quran Hadith covers multicultural insight. Some themes such as humans and their duties as caliphs on earth, democracy, fairness and honesty, tolerance and social ethics can be viewed from a multicultural perspective. Some of these themes can be interpreted into competency standards and basic competence as follows:

Tabel 1 Basic competencies of Multicultural insight-based Quran Hadith (Source: Teaching instrument of Quran Hadith teacher at MAN 2 Pontianak)

\begin{tabular}{|c|c|c|}
\hline $\begin{array}{l}\text { Competency } \\
\text { Standard }\end{array}$ & Basic Competence & Theme \\
\hline $\begin{array}{l}\text { Understanding the } \\
\text { verses of Quran about } \\
\text { humans and their } \\
\text { duties as servants of } \\
\text { Allah and caliphs on } \\
\text { earth }\end{array}$ & $\begin{array}{l}\text { 1. Translating/interpreting QS al- } \\
\text { Mu'minuun:12-14; QS al-Nahl:78; } \\
\text { QS al-Baqarah:30 and QS adz- } \\
\text { Dzaariyat: } 56 \\
\text { 2. Explaining the content of QS al- } \\
\text { Mu'minuun:12-14; QS al-Nahl:78; } \\
\text { QS al-Baqarah:30 and QS adz- } \\
\text { Dzaariyat: } 56 \\
\text { 3. Applying behavior as a servant of } \\
\text { Allah and caliph on the earth as } \\
\text { contained in QS al-Mu'minuun:12- } \\
\text { 14; QS an-Nahl:78; QSal- }\end{array}$ & $\begin{array}{l}\text { Humans and their } \\
\text { duties as servants of } \\
\text { Allah and caliphs on } \\
\text { earth }\end{array}$ \\
\hline
\end{tabular}


Baqarah:30 and QS adz-Dzaariyat:

56

\begin{tabular}{lr}
\hline Understanding the & 1. Translating/interpreting QS Ali \\
Quran verses about & Imraan 159 and QS asy-Syuura: 38. \\
democracy & 2. Explaining the content of QS Ali \\
& Imraan 159 and QS asy-Syuura : \\
& 38. \\
3. Applying democratic behavior in & life as contained in QS Ali Imraan \\
& 159 and QS Asy-Syuura: 38.
\end{tabular}

Understanding the 1. Translating/interpreting QS al- Being fair and honest

Quran verses and Maa'idah: 8-10; QS an-Nahl:90-

hadith about being 92; QS an-Nisaa': 105 and hadith

fair and honest about being fair and honest.

2. Explaining the content of QS alMaa'idah: 8-10; QS an-Nahl:90-

92; QS an-Nisaa': 105 and hadith about being fair and honest.

3. Showing people behaviour that implement QS al-Maa'idah: 8-10; QS an-Nahl:90-92; QS an-Nisaa': 105 and hadith about being fair and honest.

4. Applying the fairness and honesty in utterance and behaviour like mentioned in QS al-Maa'idah: 810; QS an-Nahl:90-92; QS anNisaa': 105 and hadith about being fair and honest.

\begin{tabular}{ll}
\hline $\begin{array}{l}\text { Understanding the } \\
\text { verses of the Quran }\end{array}$ & Kanslating/interpreting QS al- Tolerance and social \\
and hadith about & QS al-Kahfi: 29; QS al-Hujuraat: \\
tolerance and social & $10-13$ and hadith about tolerance \\
ethics & and social ethics. \\
& 2. Explaining the content of QS al- \\
& Kaafiruun: 1-6; QS Yuunus: 40- \\
& 41 ; QS al-Kahfi: 29; QS al- \\
& Hujuraat: 10-13 and hadith about \\
& tolerance and social ethics. \\
& 3. Showing people behaviour that
\end{tabular}




\begin{tabular}{l}
\hline implement QS al-Kaafiruun: 1-6; \\
QS Yuunus: 40-41;QS al-Kahfi: \\
29; QS al-Hujuraat: 10-13 and \\
hadith about tolerance and social \\
ethics. \\
4. Applying tolerant and ethical \\
behavior like mentioned in QS al- \\
Hujuraat: 10-13, QS al-Kaafiruun: \\
1-6; QS Yuunus: 40-41;QS al- \\
Kahfi: 29; and hadith about \\
tolerance and social ethics. \\
\hline
\end{tabular}

Those are some themes of Qur'an Hadith at Madrasah Aliyah Negeri 2 Pontianak that the authors reviewed from the perspective of multiculturalism in understanding several verses and hadiths concerning these themes.

Spirit of multiculturalism, for example, can be found on the theme of "tolerance and social ethics" which studies Surah al-Kaafiruun: 1-6; Surah Yunus: 40-41; Surah al-Kahf: 29; QS al-Hujuraat: 10-13 and the hadith about social ethics. In Qs al-Hujurat Verse 13 Allah SWT says "O people, indeed We create you from a man and a woman and made you nationals and tribes so that you know each other. Surely the most noble among you by Allah is the most pious among you. Indeed, Allah is All-Knowing, All-Knowing. "

In developing the material, the teacher gave this verse reinforcement. This is evident from the quotation: "The wider and stronger the introduction of sharing among people in different cultures, religions and ethnicities, the more opportunities for mutual benefit. Therefore the above verse emphasizes the need to get to know one another. This introduction is needed to draw mutual lessons and best experiences from other parties in order to increase the faith and piety to Allah SWT. The impact is reflected in the peace and well-being of human life in the world and in the hereafter." This quotation gives the description that the substance of Qs al-Hujurat verse 13 is related to people born in different condition so that they must recognize and share the goodness each other. Unfortunately, the teacher did not give enough content or interpretation to this verse in the context of the reality of plural society in Indonesia.

In the teachers' lesson plans, there were not many examples of tolerant behavior in the context of adolescent life. The teacher still gave examples of a general nature such as helping each other and respecting the other opinions. Whereas in Multiculturalism and Quran perspective, this verse becomes the starting point of multiculturalism basis, that is, Allah SWT 
made various tribes and nations. Quran states that humans are considered good or bad depending on their wisdom, not on affiliation with certain religions, groups or nations. The policy form is reflected in its devotion to Allah in providing services for nature and humanity (Sa'dan 2015).

The Quran Hadith material implicitly also emphasizes to be fair because it is an indicator of multicultural education. The suggestion to be inclusive is an important concern of the subject matter. Material content has led to efforts to provide a comprehensive understanding of diversity so that it will have an impact on awareness of respecting for diverse communities and societies. This is then in line with the reality of the Indonesian nation which consists of ethnic, national, racial, and even religious groups. This verse at least provides a guideline that basically human beings are naturally born in various sexes, ethnicities, nationalities, even religious groups. This reality should always be strengthened by teachers because it is part of spirit and basic foundation of multiculturalism.

\section{Tolerance Meaning Development in Monotheism Verses}

Islam views the knowledge dimension as an action basis (Prasetiya et al. 2018). People who are Muslims need to hold their beliefs. Tolerance does not mean to affiliate and mingle but respect and not disturb. The multiculturalism view does not necessarily make the various differences to be merged into one, especially about religious beliefs. The Quran then provides a clear limitation as set out in Qs al-Kafirun verses 1-6.

In formulating the tolerance material in Qs al-Kafirun verses 1-6, the Quran Hadith teacher at MAN 2 Pontianak had given a comprehensive presentation of the material substance. In addition to boundaries that must be met by Muslims in relation to other religious beliefs, the teacher also emphasized that the differences in religion must be respected by Muslims. They must keep Islamic principles, especially in terms of obedience to Allah SWT.

Teachers at Madrasah Aliyah Negeri 2 Pontianak had directed and attempted to contextualize the development of Quranic material with a multicultural insight. It was stated by one of MAN 2 Pontianak teachers namely Sholihin, S.Ag, M.Pd who connected several discussion materials of the Quran Hadith, such as on the theme of tolerance and ethical ethics, deliberation, justice, and democracy both in the form of teaching materials development or materials along teaching and learning process. According to him, this multicultural insight was very important and as an effort to give students a diversity understanding as multiculturalism spirit. Moreover, if it was related to the reality of Pontianak and West Kalimantan where the people are multi-ethnic and religious communities. 
The above statement can be confirmed from praxis when the teacher delivered the material about tolerance, especially in the discussion of QS al-Kafiruun verses 1-6. Students were not only emphasized to understand the context of the verse at the time of the Prophet, where there was a strict boundary between Muslims and the Quraysh about beliefs and understanding the beliefs differences. The teacher also tried to relate to the current situation and reality in which students live in a community with different religious choices and beliefs that must be respected without having to sacrifice basic principles as the basis of Muslims such as beliefs and worship. The teacher also asked students to mention various examples of religious tolerance in their daily life. It became an interesting discussion because there was a novelty in that theme.

The learning formulation made by the teacher was in line with the tolerance spirit as a basic strategy of multicultural education. It did not break through established boundaries such as in theological issues and worship procedures although the existence of beliefs beyond what was brought by the Prophet Muhaammad Saw recognized its existence. This implies that Quran provides a strict limit that tolerance in matters of religious principles is not permitted but the Qur'an also recognizes the existence of other religions without coercion. This verse is interesting to understand, bearing in mind that lately there are people groups who use religious excuses to commit violence and coercion. In addition, the Qur'an then recognizes the religion freedom.

Nevertheless, in understanding the term of tolerance as a multicultural strategy in the Qur'an, it should not be limited to a verses number such as Qs al-Kafirun Verses 1-6 above. It is necessary for a teacher to strengthen the basis of elaboration on the theme of tolerance in the Quran by providing a complete understanding by involving other texts or propositions such as in Qs Rum: 22. Allah confirms that those who have a wise view, diversity in the world is a sign of the existence of Allah power (Sa'dan 2015). Therefore, the Quran recognizes and values diversity (tolerance) because it is part of the signs of His power. Even in Surah Al-Baqarah Verse 256, the Qur'an once again affirms that there is no coercion in religious matters because between goodness and tyranny is an obvious thing whereas the will coercion is not a human right.

This view is also strengthened by Qs al-Kahfi verse 29 "Say: "The truth is from your Lord. So whoever wills - let him believe; and whoever wills - let him disbelieve. Surely We have prepared for the wrong-doers a Fire whose edges shall encompass them (the disbelievers) about. And if they ask for a rain (against the fire) they shall be showered with water like boiling, thick, melted brass which will scald their faces; evil is the drink and wretched friend (helper)!" 
This verse explains clearly that only God having the right to determine one's faith and Kufr, even God gives freedom to His servants to choose faith and kufr according to the consequences (Misrawi, 2017).

In the future, PAI teachers need to develop the meaning of the verses that are used as arguments on the theme of tolerance. Perhaps the teacher has also heard in some sermons or heard directly speaking about avoiding associating with people who have been mentioned in the Koran such as Christian Jews as "Kafir". This narrative has the potential to hurt others and result in horizontal conflict. In the interpretation of a-Misbah, we can find the meaning of "kafir" in several contexts. Kafir which means reluctance to acknowledge the impression of Allah SWT, the two kafir means reluctant to be grateful for favors and gifts, the three kafir means blocking or covering themselves and others from the path of Allah SWT, and the four kafir in the sense of making religion a game. And this meaning is the essence of the meaning of kafir (M. Quraish Shihab 2005) . While if it is seen from the semantics, the word 'kafir' refers to a ignorant society that are reluctant to accept change, a progressive mindset, against social changes such as equality and justice. Likewise the prophet Muhammad can be said to be an infidel because he did not want to accept customs that were contrary to universal values of humanism such as tribalism and individualism (Muslimin 2011).

Therefore, religious education needs to build a positive narrative about the religion around it. Even though we know that Islam is a complementary religion to the previous religions, there is no need to declare that other people besides Islam have no chance to go to heaven. The discussion that the teacher needs to develop is to explore the contextual meaning of the words Kafir and ad-Din so that they are more dynamic. The teacher can explain the historical-sociological meaning of kafir, not only the meaning of kafir as a form of denial of the Oneness of God. An example can be studied from the book Jami 'al-Bayan by al-Tabari. The word Kafir is defined as a person who denies the power of God. And the teacher can also explain that disbelief is a condition of ignorance of the Qurasy people about the truth of religion brought by the Prophet Muhammad. They still believe in their old beliefs and ideology. Thus, no teacher who teaches the word kafir and gives the label of kafir to followers of religions other than Islam will definitely go to hell. Because humans cannot predict when people will receive guidance or apostasy in the future or take action to persuade people to join Islam with the guarantee of heaven. This was also emphasized that education needs to promote socio-cultural values so that students internalize religious-based multicultural values ( $M$. Rohman and Mukhibat 2017). 
According to Misrawi (2017), the verses above indicate that the concept of no coercion in terms of religion is as a form of understanding and accommodative attitude of Islam and other religions and cultures in general. Because the aim of religion is the creation of justice and respect for humanity, so in responding to the diversity of religions and the way to disseminate religious thought products, a strong moral-ethical foundation is needed. If there is competition, it must be framed with a goodness framework, not in the framework of evil or crime with violence.

In this context, an open attitude is needed in understanding the text without neglecting the context. Likewise, educators at madrassas / schools in carrying out their duties must promote a multicultural spirit built on the foundation of understanding religious teachings which are extracted from various authoritative sources such as the opinions of scholars from various circles. Through a variety of logical arguments from the scholars, each problem will find a path of truth in accordance with the context that surrounds it (Dawing 2018). With guidelines with a comprehensive understanding, it is undoubtedly able to make students who have a tolerant attitude, appreciate sympathy or alturism as an extension of humanity (Rahmawati 2019).

\section{Meaning Development of the Verses about Justice Concept}

One of multiculturalism values in the Quran is justice spirit. In the context of Quran Hadith learning, it is reflected in Qs al-Maidah verses 8-10 " O you who have believed, be persistently standing firm for Allah, witnesses in justice, and do not let the hatred of a people prevent you from being just. Be just; that is nearer to righteousness. And fear Allah ; indeed, Allah is Acquainted with what you do (8), Allah has promised those who believe and do righteous deeds [that] for them there is forgiveness and great reward (9), But those who disbelieve and deny Our signs - those are the companions of Hellfire (10)."

This verse indicates that humans should always be fair, not only to Allah SWT but also to fellow humans. In the context of this verse, an act of justice towards fellow human beings is to fulfill the human rights and act fairly in accordance with the creatures rights. In the interpretation of Fi Zilalil Quran, Sayyid Qutub explained that the meaning of "fair" in the verse has a special characteristic, namely the unity of harmony. Justice in Islam aims to balance the capacities and limitations of individuals as well as groups in various problems such as spirituality, economy, education. Fair also gives all parties the opportunity and encourages healthy competition (Quthb 2003). 
The meaning of the word "fair" should be developed by PAI teachers, this is so that students have a broad understanding, do justice not only for themselves, their family and friends, but only for people outside the religion of Islam who have various social status. It is necessary to explain that people who behave fairly are likened to shelter and refuge for people who are persecuted. Syekh Muhammad Mutawalli Sya'rawi in the interpretation of Sya'rawi stated that justice is applied to everyone, including doing justice to the enemy. This is so that they believe that Islam is a tolerant religion and cares for the rights of others. Doing justice can encourage unbelievers to change their minds not to be hostile to Islam and ready goods that apply dholim means that they have acted in violation (Rangkuti, 2017) and classified as a behavior that breaks the agreement with Allah (Anwar, 2019 and Siradj, 2014).

Quran hadith teacher, Indasyah S. Ag., had also tried to provide a deep understanding about fair meaning. It was confirmed from students of MAN 2 Pontianak class $\mathrm{X}$ that there was explanation related daily life, like being fair if there are activities in the classroom. For the admissions committee, there must be justice in accepting new students. Starting in 2019 with the zoning system, new student selection is expected to be fair for the wider community. This was stated by J Coleman that every child needs to get a chance to excel (Coleman et al. 2019) Apart from that, it is fair to oneself and the environment. The example of being fair to the environment is not throwing garbage around the neighbors so that they feel upset.

The expansion of the meaning of the verse about justice can be carried out by the teacher by examining several interpretations. It provides a comprehensive understanding of the meaning of the thematic verse in the curriculum. An understanding of justice becomes urgent in the life of a plural society. Student life in the community will interact and may often carry out various transactions with people of different religions, ethnicities, cultures. And they must become agents of the transformation of Islamic teachings that carry the concept of universal justice. Students and the wider community need to be aware of the negative side of being selfish and greedy in many ways. The concept of fairness in society is quite manifold, from just in economy, to politics and law. Students as the nation's next generation need to be equipped with an adequate concept of justice so that one day leaders can be wise. Some of millions madrasa students in the next 10 years will be leaders from the local, national and regional levels. With the concept of justice based on the values of religious teachings and norms, the Indonesian people will be increasingly dignified (Ang, Ramayah and Amin 2015). 


\section{Meaning Development of the Verses about Democracy in Indonesia}

The democracy is also very important in multiculturalism. The Quran also addresses it as in surah Ali Imran Verse 159 which means "It was thanks to Allah's mercy that you were gentle to them. Had you been rough, hard-hearted, they would surely have scattered away from you. So pardon them, and pray for their forgiveness, and take counsel from them in matters of importance. And when you are resolved on a course of action, place your trust in Allah; surely Allah loves those who put their trust (in Him)."

The development of the meaning of the verse about democracy was also put into practice when Sholihin, M. Pd explained that deliberation was a highly recommended practice in Islam as well as part of the actualization of Islam towards democracy itself. Rasulullah gave an example in solving problems with friends and asking friends to give their opinion before it was decided. According to him, students need to be invited to understand that in the context of a pluralistic society and the problems and problems faced are quite complex. Deliberation becomes an alternative solution for both because the agreements made are based on the results of deliberations from the representation of each component of society. The teacher also develops the meaning of the verse text about deliberation through practice in discussion. Students are directed to make decisions through gathering opinions from peers because the students in the class are the same.

According to the authors, there is an important part of the development of material about deliberation that has an expanded meaning. Teachers need to refer to popular interpretations such as the work of An-Nur (Hasbi Ash Shiedieqy 1969: 106-110). In the interpretation of the verse it is emphasized that deliberation must be in accordance with the circumstances of the time, place and the psychological condition of the community. In making decisions, you should ask for opinions from friends who have the capacity to deal with the problems at hand. Then Jalalain's interpretation of the work (Jamaluddin Al-Mahalli and Jamaluddin as-Suyuti 2003: 272-273). In this interpretation it is explained that in deliberation one has to be gentle, even if someone scoffs. Deliberation is not only for the media to find solutions but also as a way of resolving to find the best decision.

This verse gives us an understanding that multiculturalism is reflected in the democracy value which in Islam is known as Musyawarah. Deliberation becomes one of the ways when it is faced with various problems involving many components or people groups. Through deliberation, it is expected that the community in a group can produce various policies that are able to be accepted by each group involved in it. In this verse, there are many things which should then be taken into consideration when conducting deliberations. First, the 
process of deliberation should be gentle, endeavor with words or diction that are not harsh, and unwarranted acceleration, Second, if there are opinion differences, they must be openhearted to accept the truth. Third is apologizing if there are words in the discussion that hurt feelings. The fourth is reciting istighfar and praying for each other so that the discussion results gets God's blessing. (Zulfikar 2019 and Rosyada 2014).

Based on the explanation above, some of the main themes in the discussion of Quran Hadith material contais the multicultural insights values and substance. The teachers'ability in terms of elaborating the content of Quran Hadith learning materials with multicultural insights such as democracy, justice and tolerance is very much needed, especially relating the materials with various diversities in Indonesia. In addition, Islamic education learning must promote multicultural values through internalization of various ways in the school/madrasah environment. It is like study conducted at Madrasah Aliyah Negeri 3 Yogyakarta three years ago (M. Rohman and Mukhibat 2017).

The effort made by MAN 2 Pontianak teacher is part of learning material contextualization. This contextualization is intended as an effort to actualize learning material to down to earth. This is like (Libriyanti 2009) stated that the material actualization must be dynamic in accordance with the needs and times, and is not coercive. The contextualization touches on empirical, down to earth, based on reality, and far from indoctrination elements. Islamic education is aimed at giving an open and critical understanding to respond the changes and taking new perspectives on developing issues.

Quran Hadith learning strived to run dynamically. According to Suryadilaga (2017), contextualization of Hadith in life must be in in line with the Qur'an as the main, especially the hadith as a history product that cannot be separated from Arab society. It needs to be understood not only from the lexical meaning, but also needs to be interpreted in other sciences so that it can explain before and after getting revelations. So, it must be interpreted appropriately in accordance with the context today.

Basically, multicultural-based Quran Hadith at MAN 2 Pontianak showed the development. The materials of multicultural values and spirit were done in some discussions, like discussion about tolerance, social ethics, democracy, and deliberation in contextualization. The discussion was done by developing themes based on the hot issues getting from newspaper and television. The examples were punishment for corruptors, ordinary criminal cases, takzir perpetrators of adultery, and other problems such as proselytizing in the digital era. The point shows Quan Hadith teaching must present the values found from the text meaning to the context meaning so that it can be dynamic. 


\section{Conclusion}

Multicultural education at MAN 2 Pontianak has developed and contextualized the Quran Hadith materials. Several themes that were relevant to encourage multicultural understanding were identified so that the teacher focused on exploring the verses meaning with a multicultural perspective.

The multicultural education process in Quran Hadith was done in some ways. They were (1) developing the tolerance meaning in terms of monotheism/belief by discussing surah al-Kafirun, (2) developing the democracy meaning, especially in Indonesia, through discussing Surah Ali Imran Verse 159; (3) developing the justice meaning, basically surah al-Maidah verses 8-10. From these themes, the teacher encouraged students to criticize the conditions that occur in real life so that they discover their own multicultural concepts and implementations through various events along the learning process.

Multicultural education is so important in maintaining diversity or diversity in Indonesia. Therefore all subjects managed by PAI teachers or teachers of other general subjects seek to expand the reading and meaning of the application of the concept of tolerance, social ethics, justice, deliberation/democracy which is constructed from the universal values of Islam and Islamic moderation (washathiyah). The learning process in schools/madrasahs is directed at strengthening the students' personality or character so that they grow and develop tolerant and empathy (alturism) attitudes to fellow humans as a manifestation of obedient servants. 


\section{REFERENCES}

Abdul Karim Munthe, et al. 2017. Meluruskan Pemahaman Hadis Kaum Jihadis. Ciputat: ElBukhari Institut.

Al Mahalli, Imam Jalaludin and As Suyuti, Imam Jalaludin. 2003. Tafsir Jalalain, jilid 1. Translated by Bahrun Abu Bakar, L.C. Bandung: Sinar Baru Algesindo.

Ang, Magdalene C.H., T. Ramayah, and Hanudin Amin. 2015. "Equality, Diversity and Inclusion : An International Journal Article Information :” An International Journal.

Anwar, Saeful. 2019. “POLA DASAR DIN AL-ISLAM.” ALQALAM.

Banks, James A. 2015. “Multicultural Education.” In International Encyclopedia of the Social \& Behavioral Sciences: Second Edition,.

Chevrier, Sylvie, Suzan Nolan, and Leila Whittemore. 2013. "Managing Multicultural Teams." In Cross-Cultural Management: Culture and Management Across the World,.

Coleman, James S. et al. 2019. "Equality of Educational Opportunity." In Equality and Achievement in Education,.

Dawing, Darlis. 2018. "Mengusung Moderasi Islam di Tengah Masyarakat Multikultural." Rausyan Fikr: Jurnal Studi Ilmu Ushuluddin dan Filsafat.

Efendi, Anwar. 2008. "Sekolah Sebagai Tempat Pesemaian Nilai Multikulturalisme." INSANIA : Jurnal Pemikiran Alternatif Kependidikan.

Haningsih, Sri. 2008. "Peran Strategis Pesantren, Madrasah Dan Sekolah Islam Di Indonesia." el-Tarbawi.

Hasbi Ash Siedieqy. 1969, Tafsír Al-Qur'anul Majid “An-Nur” juz 4 Jakarta: Bulan Bintang.

Kamal, Muhiddinur, and Junaidi. 2018. "Pengembangan Materi Pai Berwawasan Multikultural Sebagai Upaya Menanamkan Nilai-Nilai Keberagaman Siswa SMKN 1 Ampek Nagari Kabupaten Agam." Penelitian Pendidikan Islam. 
Sukino, Wahab dan Ahmad Fauzi Murliji

Kusuma, Bayu Mitra Adhyatma. 2016. "Radikalisme Di Asia Tenggara: Dinamika Relasi Agama, Konflik, Dan Kebijakan Publik.” Public Lecture Department of Public Administration Universitas 17 Agustus 1945 Jakarta.

Libriyanti, Yuyun. 2009. "Pendidikan Agama Islam Dalam Masyarakat Pluralis ( Studi Tentang PAI Pada Kelas XII SMA Se-Kabupaten Klungkung Bali).” Jurnal PAI4(1).

M. Quraish Shihab. 2005. Lentera Hati Tafsir Al-Misbah Vol.8.

MIsrawi, Zuhairi. 2017. Al-Qur'an Kitab Toleransi. Jakarta: Gramedia Widisarana Indonesia.

Muliadi, Erlan. 2012. "Urgensi Pembelajaran Pendidikan Agama Islam Berbasis Multikultural Di Sekolah.” Jurnal Pendidikan Islam.

Muslimin, Imam. 2011. “Tafsir Semantik terhadap Surat Al-Kafirun.” LiNGUA: Jurnal Ilmu Bahasa dan Sastra.

Prasetiya, Benny et al. 2018. "Penguatan Nilai Ketauhidan Dalam Praksis Pendidikan Islam." Journal of Islamic Education (JIE).

Quthb, Sayyid. 2003. “Tafsir Fi Zhilalil Quran.” In Jilid 7,.

Rahmawati, Sri W. 2019. "Peran Iklim Sekolah Islami terhadap Altruisme (Tindakan Kemanusiaan untuk Menolong Orang Lain).” Edukasia : Jurnal Penelitian Pendidikan Islam.

Rangkuti, Afifa. 2017. “Konsep Keadilan Dalam Perspektif Islam.” Jurnal Pendidikan Islam.

Rohman, Abdul, and Yenni Eria Ningsih. 2018. "Pendidikan Multikultural: Penguatan Identitas Nasional Di Era Revolusi Industri 4.0.” UNWAHA Jombang.

Rohman, Miftahur, and Mukhibat Mukhibat. 2017. "Internalisasi Nilai-Nilai Sosio-Kultural Berbasis Etno-Religi di MAN Yogyakarta III.” Edukasia : Jurnal Penelitian Pendidikan Islam.

Rosyada, Dede. 2014. "Pendidikan Multikultural di Indonesia Sebuah Pandangan Konsepsional." Sosio Didaktika: Social Science Education Journal.

Sa'dan, Masthuriyah. 2015. "Nilai-Nilai Multikulturalisme Dalam Al-Qur'an Dan Urgensi Sikap Keberagamaan Multikulturalis Untuk Masyarakat Indonesia." Jurnal Toleransileransi 7(1). 
Shihab, M. Quraish. 2002. Tafsir al-Misbah; Kesan, Pesan dan Keserasian Al Qur'an, vol 2 ed.l, Jakarta: Lentera Hati.

Siradj, Said Aqiel. 2014. "Tauhid Dalam Perspektif Tasawuf." ISLAMICA: Jurnal Studi Keislaman.

Spring, Joel, and Joel Spring. 2018. "Multicultural Minds." In The Intersection of Cultures,

Sugiyono. 2014. "Memahami Penelitian Kualitatif." Bandung: Alfabeta.

Suparlan, Parsudi. 2014. "Menuju Masyarakat Indonesia Yang Multikultural." Antropologi Indonesia.

Suryadilaga, Muhammad Alfatih. 2017. "Kontekstualisasi Hadits Dalam Kehidupan Berbangsa Dan Berbudaya." Kalam, 11(1): 215-34.

Tilaar, H.A.R. 2002. Perubahan Sosial Dan Pendidikan: Pengantar Pendagogik Dan Transformatif Untuk Indonesia. Jakarta: Grasindo.

Zuhdi, Muhammad Harfin. 2010. "Fundamentalisme Dan Upaya Deradikalisasi Pemahaman Al-Qur’an Dan Hadis.” Religia.

Zulfikar, Eko. 2019. "Etika Diskusi dalam Perspektif Al-Qur'an." Jurnal Studi Ilmu-ilmu AlQur'an dan Hadis. 
